p.40 体育 学 研 究 X-1

中国正史にみられる体青について（その1） 神奈川県立西湘澶等学校 鈴 木 藏

1.はじめに

従来の中国体育史の研究は，日本体育史・西洋体育史 のそれにくらべて非常に立ち遅れている。たとえば，歴 史学研究の初歩ともいらべき基本的史料の収集が殆んど おこなわれていなからた，そこでこの点を遗憾としてて， 今问中国体育史においても，基本的史料の収集を試みて みた。

基本的史料の収集といら観点から，中国史研究におい て，最も史料として基本的文献である正史の5ち史記を とりあげ，その文献中より体育に関するるのを探し出し てみた。しかし原典の読みに追われ，収集したものを十 分吟味するまでに至らないのが残念である。

\section{2. 正史一特に史䪧について一}

正史すなわち 24 史とは，正統な史書といら意味で， 史記・漢書の体裁に準じて作られた紀伝体の史畫であ り，本紀・列伝を中心として志類・表などから構成され ている．清の乾隆年間，勅命により各王朝の粑伝体の史 書 24 種を選しで正史としたので 24 史の名が一般に打こ なわれている，中華民国になり新元史が正史に加えられ たので 25 史とむいわれ，中国史研究上の最も基本的な 文献である.

史記は，史書の典型とされる中国古代の通史で，前漢 の司馬選の著で，本紀 12 ・表 10 ・畫 8 ・世家 30 ・列伝 70 の計 130 巻である. 成立は B.C. 91 年頃ひとまずそ の草稿を完成したとみられる，史記の中には，各所に後 人の補筆にかかる部分が少なからす混入しているが，全 休的に見るならば，司馬選個人の手になる独創的な歴史 であることに変わりはない，史書としては，黄帝から前 漢の武帝の晚件までの歴史を多様な形式によつて総合的 に記述した. 本紀は政治的事件を編年的に記述した年代 記である．表は古代王朝の系図・春秋戦国の対照年表・ 漢初諸候の年表・幸相大臣の在職年表等を含む。畫は礼

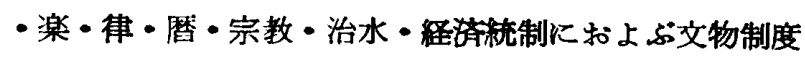
史である．著者は漢朝の太史家に伝わつた文献の他に， 天下を周遊して史跡を訪れ，同時代の口碑等を採集し， これに基ついて史記を編纂した，その利用しえた史料は かならずしも十分とはいえないが，よくこれを駆使し
て，大著述をなしたのである

\section{3. 史婄にみられる体音について その1}

本研究に批いては正史の5ち史記の本紀・表・書計30 巻について体育に関する史料の収集を試みた，以下は简 単なまとめである。

(1)収集した史料は全部で40であつた。

(2)それらを整理すると，A弓術に関するもの（弓の名 手，弓を教える，騎射の名手，強弓の名手，游射，射 牛，郎村の射礼，邚外の学宮での射，東学での射，西学 での射，天子の大射の礼を括こなら処，諸候の整射を習 つた処，打扎しかを射つ，大弓に四矢をつがえて射つ）。 B力技に関するるの（力自慢で重い將をあげ肋骨を和つ た）、C舞に関するるの（剣舞，高祖が舞5，武徳・文 始の舞，文始・五行の舞，昭徳の舞，始めて楽舞を用 5.楽とは武舞・文舞飞合わせるるの，鐘鼓・干践は舞 楽を和す. 干威の舞，舞楽の行列の長短，干揚の舞，歌

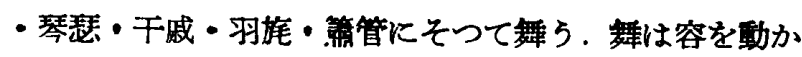

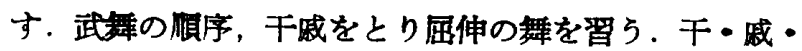
统・狄をとつて舞 5。武舞の内容とその説明．天・地を 祭るのに楽舞を用いる．跂舞の楽)，D 養生に咸するる

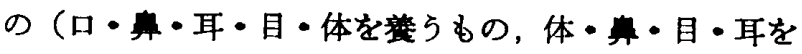

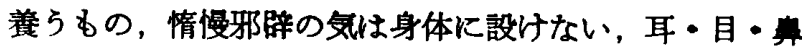
・口・心・知の百体を順正働かす．三老五更を太学に

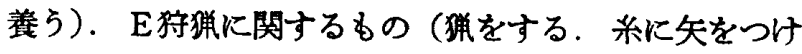
て鳥をとる)，F 雞闘闻するもの（諸候の子弟や金持 が雞闢をやった），G 走狗馬に関するるの（諸候の子弟 や金持が，ドッグレース・競馬をやつた）.

以上のような結果であるが，前述のように収集した史 料に関する十分な吟味を加觉ていないが，これは以後の 世家 30 巻・列伝 70 巻ととるに解明していきたい。

なお最後に以上の上らな諸事項が原典のどの巻に入つ ているかを罕考まで記しておくと，Aは（周本紀，秦 始皇本紀 2 , 高祖本䄫, 孝武本紀 3, 楽書 3, 封禅書 10) にあり，Bは（秦本紀）にあり，Cは（項羽本紀 3 , 高 祖本紀，孝武本紀，楽書 11 ，封神畵 3) にあり，Dは 礼書 2, 楽書 2) にあり， E は（封禅書，平準書 2) に あり， $\mathrm{F}$ (平準書)にあり， $\mathrm{G}$ は（平潐書）にそれぞ れ含まれている.〔註. 数字は史料数を示す.】 